\title{
The Alignment between Strategies and Competence: A Study of the Customer Service in the Educational Area
}

\author{
Alyne Bento de Lima Brianezi ${ }^{1}$, Samuel Carvalho De Benedicto ${ }^{*}$, Edilei \\ Rodrigues de Lames ${ }^{1}$, Cibele Roberta Sugahara ${ }^{2}$, Candido Ferreira Silva Filho ${ }^{2}$ \\ 1.UNASP-Hortolândia-SP Brasil. Rua Pastor Hugo Gegembauer, 265-Parque Ortolândia, Hortolândia/SP- \\ Brasil, CEP 13184-010. \\ 2.Pontifícia Universidade Católica de Campinas. Rod. Dom Pedro I, Km 136-Parque das Universidades. \\ CEP13086-900 Campinas/SP-Brasil.
}

*Corresponding Author: Samuel Carvalho De Benedicto

\begin{abstract}
The current study is a scientific investigation whose objective is to research the relevance of the alignment between strategy and competences in customer service in the educational area. Due to the market competition, the strategic alignment has stood out as a competitive advantage in organizations. In search for this alignment, it is essential for companies to map the competences of the officers who represent them, in addition to defining which competences are necessary for each situation inside the organizations. To deepen the empirical standpoint, a case study of qualitative nature in the customer service was carried out in an Educational Institution (Basic Education and Higher Education) in the Campinas Metropolitan Area/SP. The results of the work reveal that the necessary competences are determined by the customer service team managers. In the team, a high rate of collaborators who possess the necessary competences in customer service was identified. The practical relevance of the corporative processes and their possibilities through the mapping of the competences were executed.
\end{abstract}

Keywords: Strategies, Strategic alignment, Competences, Educational Area.

\section{Introduction}

The corporate strategy is present in all the companies structured in a systemic and organized way. It reflects the steps that it should follow for the decision-making and different contexts in its routine [1]. The way that the organization acts strategically, reflects upon its competitive performance [2].

That performance involves directly the human resource area, in other words, the people who work in the organization [3]. In the view of several authors, [4, 5], the organizational strategy is the way the company is related to the market. According [6] sorts of relationship as a qualified set of people, operational excellence, products innovation and customer-related relationship; the company defines which way it wants to follow. According to [6], after the strategy, there are the competencies. For [7] relate the competences to a set of organization attributes.
Brandão and Bahry affirm that "it is possible, then, to classify the competencies as humans or professionals (those related to individuals or to small work teams) and organizational (those inherent to the whole organization or to one of their production units)".

The competences should be developed and/or researched within a context, whether in the personal, professional and/or organizational field. The aim of this study is to search the relevance of the alignment between strategy and competence and to conduct a mapping of the existing competences in the group of collaborators of customers helping a company from the educational sector.

To achieve its objective, this investigation is a case study carried out in a company in the state of São Paulo, in the metropolitan area of Campinas. 
That company is an educational service supplier from a private school network.

The methodological stance of this study is hypothetical-deductive and its nature is qualitative. The study becomes relevant by the contemporaneous organizational approach and by the difficulty of finding qualitative studies with deep analysis related to the theme "the alignment of competences and strategies related to the help of the client."

\section{Theoretical Foundation}

This section reviews a few principles and concepts present in the literature related to the organizational strategies and competencies, seeking to elucidate the theoretical line adopted in the context of the work. It stands out, in special, the relevance of the alignment between strategy and competency through the value addition. In search of alignment, it is essential for companies to map the competencies of the employees that represent the company, in addition to defining which are the necessary competencies for each situation within the organization.

\section{Corporate Strategy and its Relevance}

Strategy is present in all the companies structured in a systemic and organized way. It reflects the steps that they should follow for their decision-making and different contexts in its daily routine [1]. The way the organization acts strategically reflects on its competitive performance [2]. However [9] stresses that any strategic action aiming at a competitive performance passes by the human resources of the company; therefore, it's necessary for the companies to have skilled people to act strategically. According to [10], due to the instabilities of the competitive environment, it is necessary for companies to have professionals who, besides know how to do some tasks, they know how to act in a creative and innovative way in professional contexts which have been growing in a large scale.

But, according to [11], in spite of this speech, few organizations are found in competitive environments which are willing to open space to stimulate autonomy for such innovations to happen. The author defines that both control and centralization are still the main focus of organizational strategies that support changes. From that, [10] affirm that "the solution, therefore, is not to reform the current model of people management but rather to work a new archetype, conceptually thought to meet the management needs focused on the "competence approach". In the definition of strategy according to the concept of Alfred Chandler Who, that in 1962, presented studies and analyses about the best kinds of organizations management, based on the mutations of North-American companies in that century [12]. The authors call the attention to the fact that Chandler has already guided his concept to a strategic thinking related to alignment; where strategy involves goals and objectives on the long run.

To some authors [4,5], organizational strategy is the way the companies relate to the market. The kind of relationships for [6] is: qualified set of people, professional excellence, product innovation and customeroriented relationship; the companies define which ways they want to follow. Currently, we live in the era of knowledge, of shared knowledge, that is, the individuals have more and more access to information [13].

Those results into a more qualified being while a consumer. Organizations, besides meeting consumer's needs, must have a competitive differential. Something which is responsible for both engaging and warranting the customer preference, being able to add value to the services and/or products offered [14].

Treacy Met. al. [15] Support that the organization that has value addition possesses competitive advantage in relation to the others. According to De Benedicto SC et. al. [16] the value is added through the experience that the company offers to the customer, giving something which provides him relevant experiences, but also following the proposal of the alignment. Munk L et. al. [12] say that "the creation of value originates in the adjustment between internal resources and strategy, and the strategy originates in the competitive environment".

Then, it is necessary to use the same semantics, aiming at the alignment between both. In their study [11] discuss how the alignment instruments can make the management and the communication of the strategic process easier by the mapping and development of organizational competencies. Visually, the organizational strategy is configured through its mission, vision and 
values [17]. The mission aims to present the reason and the purpose by which that company exists. The vision is where the organization wants to reach, how it sees itself in the market in the medium and long term. And the values represent the way that the company will use its behavior to conquer and/or maintain the other items-mission and vision [18].

According to Le Boterf $\mathrm{G}$ et. Al. [19], the mission, vision and values of the company lose their function when they transfigure into the organizational culture. Both culture and behavior reflect the capacity of the company in daily actions. In other words, despite the strategies the organizational administration establishes, the vision of how it should be and the behavior in theory (vision, mission and values), in practice, it is the culture which reflects the internalization of these postulates, being able either to be or not aligned to the theory.

\section{Mapping and Alignment of Strategies and Competencies}

An organization becomes alive through the composition of its activities and responsibilities by people [20]. Each organization holds unique peculiarities, then, in the recruitment and selection process, it is essential for the company to concern about observing the candidates, the individual characteristics, their competencies, considering that these characteristics are compatible with the profile, with the organizational strategies [21].

For Belfort RM et. al. [22] state that "each collaborator knows or can learn to identify his adequate competencies, skills, strong and weak points and also his goals, being him the only person capable of deciding what is better for himself".

The human resources area has the incumbency of contributing for this collaborator to exercise his competencies in association with the organizations. According to the authors, for that to happen, it is necessary for the company to invest into development, providing continuous conditions for that professional to develop himself. The term competence has been the current subject in the corporative universe due to its complexity and relevance.
For Fleury A [23], competence is a set of knowledge, skills and attitudes which explains a superior performance, considering that the performance is grounded on intelligence and the personality of individuals. Competence as a meeting of three axes: people (biography, socialization), educational background and professional experience [19].

In agreement with the statement presented, Dias AT et. al. [24] state that all the knowledge and experience contributes toward the individual's performance in the circumstances represented by behavioral actions. Endorsing that premise, the contribution by Brandao HP [8] follows "human or professional competences are understood as synergic contributions of knowledge, skills and attitudes, expressed by the professional performance in a given context or in certain organizational strategy".

Competence as a cluster of characteristics in the individual related to knowledge, skills and attitudes, which result into improved performance, beyond the expected [25]. And it develops more and more in each situation, actions and resolutions. Ferreria DAF et. al. [9] Affirms that the perception of these characteristics is valued by the company, it is possible for the company to manage, develop or guide an adequate alignment with its own strategies to happen.

When Le Boterf G et. al. [19] writes that the professional is a situation - man, he contextualizes competences explaining that the quality of what a person performs is the capacity of acting and discerning degrees of complexity of the adverse situations, choosing a behavior for each scenario. The actions of people, according to Zarifian $\mathrm{P}$ et. al. [26], as a result of the circumstances, define their competences and Prahalad CK [7] state that these competences serve as a linking between the individual behavior and the company strategy. Thenceforth, one can infer that employee's actions are endorsed on his personal capacity of solving and following the settings given by the company. And the people's competences are expressed in their actions.

However, it is stressed that the competences are not only linked to people individually [27]. 
If competences are characterized in part by the action capacity, one can consider that the same can be carried out by groups or teams.

In this sense, Brandão HP et. al. [8] mention that "in each work team, a collective competence expresses itself, which emerges from the social relationships which are established in the group and from the synergies among the individual competences of its members". Faria S et. al. [28] Also contextualize competence beyond individuality, placing that "competence expresses actions autonomy of the individual in a work team or network who engages subjectively and voluntarily by the virtue of their initiatives in improving produced value".

However, Prahalad CK et. al. [7] relate competence as an organization attribute. Brandão HP et. al. [8] Affirm that "it is possible, then, to classify competences as humans or professionals (those related to individuals or to small work teams) and organizational (those inherent to all organization or to one of its production units)". Competences will be developed and/or researched always within a context, whether in the personal, professional and/or organizational field.

Leme R [29] Exposes the competence from its pillars, the CHA, which means: (i) knowledge -what we learn in the school benches, books and work; (ii) skill-the know how to do of our knowledge; (iii) attitude-the demonstration of skill by an action from knowledge. Belfort RM et. al. [22] Summarize this stating that "competences are almost all localized in the actions of people in organizations. They constitute the rational and intelligent basis of the entrepreneurial action". Considering that the organization has defined strategies, the great challenge is having a team which represents them faithfully and in a satisfactory way for the company to reach its objectives [30].

The talent retention is a part of the routine of all organizations, always with the same objective: filtrate individuals who hold competences that are aligned to the company strategies [31]. To warrant the efficacy of this process, it is indispensable to the organization to map what are the competences of its team, either individually or as a group, to make the development of the proposals of the organization easier, in addition to defining in its strategies which competences are necessary for each function and/or activity [32].

According to Gimenes $\mathrm{CH}$ [33], the mapping is a process where the skills available in the company are identified to; afterwards, verify if they are compatible with the necessary skills to fulfill the corporate strategy. According to Ferreria DAF et. al. [9], the mapping is relevant because of the support that it offers to the implementation of the development actions to deal with the differences that are found between the existing competences and the required competences.

Within the company, the responsibility of managing these issues is from the human resource manager, which seeks to match the organizational goals and personal competences. "From that differentiation originates the theory that divides competences into personal, when related to the professionals and core competences when connected to the organizations themselves." For [34] the core competencies are responsible for the acting of the company on the competitive market.

Personal competences follow the need of valuing the collaborator, opened to innovations, seeking individuals with unique profiles and high performance. Competences can have variations according to the context where it is going to be analyzed [35]. In this study, the focus is the individual competences aligned to the corporate strategies.

The [10] question how to know whether the development and the choice of competences within an organization are right or not. And they have as an answer to their question what [23] propose (2001), a step by step process: definition of the strategy of the business; identification of the essential competences and of the competence of the several company areas; and after that, the alignment of the essential competences and the company areas. That vision matches the scenario proposed in the case study, the one of analyzing the alignment between the parts the planned and the executed one. Alignment works as a mathematical sign of equal (=).

When the corporate strategy is aligned to the competences of its collaborators, it means that the semantics used for the relationship and the communication is the same. 
The language used inside an organization needs to be only one.

For that to occur with efficacy, it is necessary the communication and the parameters to be known in an equal way by everybody who is part of the company. The development is also a factor which needs to be present in all the organizational processes for the competences not to stagnate and may be constantly improved [36].

Kaplan R et. al. [37] State that today methods and uses of tools management and communication for the whole company are discussed with the purpose of understanding if what was planning is aligned with what was executed. Popularly, the alignment needs to "speak the same language" for the organization to become sustainable and perennial. The authors, who cite this concept, complete it saying that it is not common for the company to have collective efforts if the orientations to the teams which perform them were not clear. And to have transparence and competence on the teams, the definition of the competences of the organization needs to be present in the organizational strategy.

For Moreira WR et. al. [10] discuss in a satisfactory way in this study when they present an approach model which integrates the alignment between the external and internal opportunities. This is an approach which consists in a two-way road of learning, for being a dynamic movement. "The development of the essential competences and the areas depends on the levering of the individual competences, which will bring about best possibilities to reach the business strategy”.

Place the stimulus of synchronizing the individual competences and organizational competences as one of the main contributions of the competences management model [9].

Oliveira AAR et. al. [38] Summarize the mapping of the competences into two steps: a survey of the entrepreneurial competencies and an analysis of the human competencies acquired and developed individually, considering the reach of the success of the drawn strategy. According to the description of Amaral et al., the mapping can be carried out through several techniques, but the ones that stand out: (i) interview - to interview the collaborators and verify what experiences they underwent; (ii) observation-to analyze the work of the collaborators writing down and checking the results; (iii) simulationthrough information, to try to draw forecast situations of the market trends. Each context and each organization should define what the effective methods in their reality are.

But, the important is transparency, communication and the strategy constructed in order to reach the alignment using the mapping and analysis. Ferreria DAF et. al [9] add, the questionnaire "it is the most relevant technique to map the competency in an organizational context, such an instrument that demands support tools like the documental analysis and interviews" as used in this study.

\section{Methodology}

For Santos FMT et. al. [40] "the methodology is understood as a flexible cluster of guidelines linking the theoretical paradigms to the investigation strategies and to the methods for the collection and analysis of empirical materials". It is through the methodology that are specified the parameters which will be used in the research, with the purpose of validating them scientifically. According to Laville C [41], the methodological aspects need to be defined coherently to the research proposal, to the theoretical assumptions and to the nature of the investigation. The methodological stance of this study followed the hypotheticaldeductive approach, where there was a triangulation between induction and deduction.

That stance, in agreement with [16] is adequate to organizational an study, that is the case of the current study. The nature of the investigation used for this research is qualitative, that according to Gil AC [42] can describe the complexity of a certain problem, understands and classifies dynamic processes in social groups; contributes towards the change process of certain groups and enables, to greater extent, the understanding of the particularities of the behavior of individuals and organizations. The case study was used as a research strategy. This approach allows the researcher to conduct an in loco checking of the research problematic in a deep range.

For Yin RK [43] the case study as a form of conducting empirical social research and the investigation of a current phenomenon contextualized by reality, but, the borders 
between the phenomenon and the context are not yet defined with great clarity. The choice of the sampling is non-probability, taking into consideration the easy access of the researchers, as instructed by Oliveira TMV [44]. The case study was carried out in a company in the state of São Paulo, situated in the metropolitan area of Campinas. It is an educational service supplier that belongs to the private education network. Nowadays, the Education Institution (IE) offers Basic Education and Higher Learning for Undergraduate and Graduate Students. The sectors inside the IE are divided strategically, so that the customers may be served according to their needs.

The work was applied to one of its sectors, punctuated by the organization as having a high importance: the customer service. The customers receive services by three teams: personal, information and telephonic service center. And those three teams were chosen to contribute towards the present study under the agreement of its managers.

Data collection was conducted by the following methods: (i) consulting to organization documents; (ii) observation in the work place of the attendants; (iii) interview with semi-structured script with three managers acting in the IE customer service area. It identified the necessary competencies to act with the customer service established as an organizational strategy of the company; (iv) unstructured questionnaire application to the group of collaborators related to the managers: the questionnaire was constructed from the indicators present in the research of primary data with the purpose of identifying the individual competencies of the group who work with customer service.

The issues which guided the research were: what is the relevance of the alignment between strategy and competency in the organization? In what manner is it possible to perform this alignment? Does the studied organization know about this thematic? From these advices and inside the proposal presented, the analysis and presentation of the data were carried out by the tool "Explanation Building". De Benedicto SC [45] Defines this tool as a strategy focused on exploring the study object through explanation, in addition to extracting relevant aspects to discussion.
This strategy of qualitative data analysis allows constructing an analytical repertoire using the narrative mode. Then, the explanations are constructed in order to reflect the significant theoretical propositions, giving emphasis to what really matters, that is, confronting the theoretical elements with the findings of the research.

The explanation construction was undertaken through the analytical narration of the data dialoguing with the guiding issues of the study. The empirical analysis was conducted from the background obtained in the scanning performed in the literature belonging to the subject proposed. The analysis of analytical descriptive nature intended to promote thinking and the importance of the pedagogic strategic alignment of competencies related to the service of the customer service area.

\section{Analysis and Discussion of Results}

Research has brought some proposals already placed into context in the previous steps of the study; it had the support of experts who have contributed over the years with relevant concepts to the academic and organizational scenario. From here, results of the data survey accompanied of empirical analysis will be presented. The study was planned and divided to be carried out in three parts not necessarily isolated in relation to time. For that purpose, the orientation approach by Gimenes CH [33] defends that; first of all, one should "identify the necessary competencies (organizational and professional) to the consecution of the organization objectives".

That is performed by conducting "a documental research which includes the analysis of the content of the mission, the vision of future, the objectives and other documents related to the organizational strategy". From that orientation, as a part of the documental study, an investigation was conducted in relation to the mission, vision and objectives of the Education Institution researched, in addition to other documental surveys which will be presented during the explanation.

The company vision is: "to be an Educational Institution recognized by the excellence in the rendered services, by its high ethical Standards and by the personal and professional quality of its former students". What can be realized is that the investigated 
EI has interest to receive recognition by the excellence of the services rendered. It shows that it concerns about the service that its customers receive.

For that to be reached successfully there must be an alignment between the strategy and the human competencies belonging to the ones who supply the services. The expected reward is also described by the high ethic standards and by the personal and professional quality of its former students. It is considered from this phrase that ethics is an important factor to the organization, understanding that it should be present in any activity and/or worker who is inside the company, both with the professionals and with the customers-the students.

But, in spite of ethics being a characteristic inherent to the human being, it is directly linked to the people' character. At last, the fact of warranting that the people who are involved with the company are all committed with the high standards of ethics is complex. In addition to ethics, the personal and professional quality of the former students is also emphasized and this accompanies the same responsibility previously cited about ethics. It is suggested that the quality of a company, in other words, of the product and/or service that it offers, needs to be surrounded by parameters which enable the perception of the quality levels. At first, the personal and professional quality of the former students might also be ruled on their competencies.

To a trustable monitoring, the mapping of the individual and/or professional competencies of the customers would be necessary to analyze them in conjunction with the organizational competencies and strategies defined and carry out a monitoring during the course, considering a comparative investigation of the competencies of the customers while former students: if the competencies on completing the course are aligned with its proposal, the quality would be at its highest level, considering thus a high standard offered. The company mission is: "to educate in the context of the biblical values for a full living and for excellence in the service to God and to mankind".

The analysis needs to consider the company mission and the proposal of educating in the context of biblical values for a full living. First of all, it is interesting to remember that the mission of a company reflects the essence by which that business exists. The mission of the investigated company is described in depth and also makes people think in an equal way. The Education Institution, whatever it may be, receives responsibility which exceeds those of the companies which offer basic need products or services. The educational segment involves the development of the human being in a holistic way.

Schools today develop a very important role in a child's and youngster's lifetime, which goes beyond the teaching-learning process of reading and writing. In the classroom, they learn to live in community, to become acquainted with the others, to respect, to understand citizenship, to love the neighbor, among so many other relevant considerations which is not the objective of this study proposal.

For being a confessional teaching institution, it follows a philosophy which matches the religious organization that manages it; therefore, the Christian biblical values are described as a source of behavior and corporate strategy. In addition, the same one is also a philanthropic institution which grants percentages of scholarships to needy students and serves the community through integration projects, which exemplifies the service to God and mankind described. It can be realized that the word excellence appears again, which shows a high degree of importance that the EI places in what it does and offers. The motto of the company is: "to educate and serve".

The motto is represented by two verbs, which makes us reflect into a conjugation of actions. In this case, it implies that there are parameters used to guide all the people inside the organization. Independently of their power, whatever they do, the focus will always be the one of educating and serving, which is positive for the people not to become defocused in the organization. From that, it is expected the organizational culture to be grounded within these standards. Analyzing it in a strategic way, "in its documents" the IE studied adopts excellence as a single standard for its activities, that is, the operational excellence proposed by Fleury A [6] as one of the options of relationship with the market, that is indispensable that it is well known by everybody inside the company. 
In continuity to that suggested by Gimenes $\mathrm{CH}$ [33], through the documental survey, interview and observation, it was realized that the EI studied presents a consolidated physical structure for the customer service, both in physical space - acclimatized, organized and centralized area to actions for the customers' interests who look for the area and the technological and process structure; offers telephone and virtual service for both customers and interested people.

The EI counts also on an electric vehicle to provide the customers comfort in the external area where there are the buildings - school buildings, library, sports complex (artistic gymnastics gymnasium, multisport gymnasium, covered courts, athletics track, soccer field, heated and covered swimming pool, gym, school, refectory, psychology office, female and male housing and temple. In the central building, as it is called, there is the administrative office and the customer service.

The customer service is divided into three teams-bureaucratic service (enrollment, assertions, document requests, student finances, charges, cashier's offices, student identification); physical service of information (general and particular information about the services supplied by the EI) and virtual and/or telephone service (general information, phone call routing, information about bureaucratic procedures, request of resolution of contractual needs-tuitions, bank ticket, collection; academic needs - marks, absences, notices, delays, among others).

The physical service is carried out in the service booths or in specialized rooms according to the customer's need. The telephone service is conducted through the PABX call system; and the virtual service is carried out through the EI internet page, by the CHAT ON LINE, in addition to the service offered through the corporate e-mail made available to all the group of collaborators who use this means of communication with customers and internal mates. For being an EI which offers Basic Education and Higher Learning, it works for public services in the central building beyond business hours (from $08 \mathrm{~h}$ to $18 \mathrm{~h}$ ) and goes until $21 \mathrm{~h}$, with both telephone service and bureaucratic service.
The online service affords an off line record, even not having service in real time, the customer can leave recorded on the internet page what he needs and in the next day, someone of the service team keeps contact to serve him. The EI, through its service proves to be highly flexible for customers' needs, which is positive for the outstanding proposal of its services. The technological platform used meets satisfactorily the EI needs, being ahead of other institutions of the same size, in agreement with the technology manager.

Another relevant factor to be placed here is the fact that in all the documents made available to the investigation of this study, the organizational and professional competencies are stressed as essential, with the emphasis in serving different contextsenvironment and behavior. The empiric sensitivity in this sense focused strongly on these statements. In addition to the collection of documental data, also an observation in relation to the routines of customer service was conducted, considering if there is an alignment between the theory and practice.

Analyzing the professionals through the verbal and body behavior of the collaborators, a calm and serene stance is noticed, without negative agitation and excessive anxiety. Oscillations in the behavior of the customer served were observed. In some moments, they were satisfied, in others the body and verbal expressions reflected a strain or dissatisfaction in relation to the service received. What is suggested for the continuity of the study is to conduct a research with the customers and check the dissatisfaction indicators with the objective of recognizing if dissatisfaction is related to the existing competencies.

The observations from [33] who state that "other methods and other research techniques, like for example, the observation, the focal groups and the structured questionnaires can still be used..... [46] Stand out that the observation in the competence mapping allows the perception of the details concerning the performance of people, identifying data which could be hidden by the respondents. Next, the results of the research conducted with the three managers responsible for the customer service-call central, information central and telephone exchange will be presented. This step follows the orientations by [33]. 
According to the author, after the first step, a data collection with key people of the organization should be done for such data to be compared with the documentary analysis. This step of the data collection intended to investigate which are the necessary competencies for customers to be served with excellence, as the strategic vision of the company proposes.
The managers interviewed were characterized by initials: Manager CA, Manager CT and Manager CI. The local services investigated have peculiarities in common - in its majority: personal, telephone and virtual service. The customers' needs follow the same focus: information and processes of service hiring. Below, there are the profiles of the managers:

Table 1: Profile of the managers researched

\begin{tabular}{|c|c|c|c|}
\hline Managers & Gender & Time in the sector & Educational Background \\
\hline Manager CA & Male & 1 year & Undergraduate - Management \\
\hline Manager CI & Female & 10 months & Undergraduate - Management (Attending) \\
\hline Manager CT & Female & 1 year and 5 months & Undergraduate - Management \\
\hline
\end{tabular}

Source: Research Data

In analyzing the chart above, some considerations can be done: (i) Time of the managers in the sector: a certain experience is presented, considering that all have already gone through all the sector routines which occur within one year, except the CI which holds 10 months' experience. But, during the interview, the piece of information that this manager was already working with customer service in the CT area in another function is found. All of them have already gone through the routine of one year inside the customer service, which theoretically would generate adequate experience for them to inform the researchers which are the necessary competencies for the customer service.

However, it is asked: would the quality of the know-how necessary for the practice of a good service be linked to the time in the post? Surely not, for other factors such as training, development, learning capacity and the perception of employees present a significant weight in this process. On the other hand, also the turnover in that field of work can influence the perception of competencies, as [46] defends. Another item of analysis is the educational background of the managers. All of them took or are taking a management course, which help them in the function of manager and to have know-how to describe their competencies.

Twenty competencies which are part of a "professional competency evaluation software were presented to the managers (separately)" [47]. There, the managers should identify the necessary and expected competencies to offer outstanding service to the customer. They are:

\section{Work under Pressure}

Ability to work under pressure in any circumstances;

\section{Self-Development}

Ability to seek constantly personal and professional improvement;

\section{Self-Motivation}

Ability to motivate oneself, directing one's forces to reach a goal

\section{Written Communication}

Ability to express one through writing in a clear and objective way, warranting that the reader understands him;

\section{Oral Communication}

Ability to express oneself orally through dialogues, talks, speeches and discussions of ideas in a clear and objective way, warranting the understanding among people and making the dissemination and understanding of the objectives easy;

\section{Creativity and Innovation}

Ability of conceiving innovative, feasible and adequate solutions to meet a need or purpose;

\section{Entrepreneurship}

Ability to identify business opportunities or solutions and put them into practice taking over its risks;

\section{Flexibility}

Ability to adapt oneself to the changes and to the different scenarios present in the environment;

\section{Conflict Management}

Ability to seek alternatives reducing conflict situations which are harming the group; 


\section{Leadership}

Ability to influence and inspire people and teams, to reach organizational objectives promoting the development of people and business;

\section{Negotiation}

Ability to conduct the understanding between the interested parts in an objective, promoting an adequate communication channel with the objective of reaching a mutually satisfactory agreement;

\section{Organization}

Ability to establish and monitor one's processes and work material in a logical, clear and productive way;

\section{Quality Orientation}

Ability to warrant that the quality and productivity standards are being met;

\section{Customer Orientation}

Ability to know the customer, identifying his needs and wishes, declared or not, offering solutions which meet and surpass his expectations;

\section{Outcome Orientation}

Ability to engage to reach the outcomes, taking the necessary actions to meet the objectives in the due time and with the planned characteristics;

\section{Planning}

Ability to structure and prioritize a series of actions with the objective of reaching a given outcome;

\section{Interpersonal Relationship}

Ability to interact with the others in an emphatic and respectful way, even in conflicting situations, maintaining a stimulating relationship;

\section{Decision-Making}

Ability of identifying and choosing the most adequate alternative to implement an action or to solve a problem;

\section{Team Work}

Genuine willingness to act in a group, collaboratively, respecting individual differences, sharing their knowledge and contributing to the achievement of common goals;

\section{Systemic Vision}

Ability to understand the environment in which it is globally involved, perceiving the interdependence between the parts, visualizing trends and the possible impacts of an action.

In addition to those capacities, the researchers also took into account some"fundamental principles of the excellent service" proposed by the Performance Research Associates (2008): to understand what is a good service under the customer's optics, people need to know what they are doing, how to do the activities, having quality, creating an unforgettable experience to the customer, satisfying the customer's needs, knowing how to negotiate, creating opportunities.

The client evaluates the service based upon five factors: reliability, empathy, safety, appearance and good will. From these contributions, we will continue with the research results with the managers. Below, it follows through the chart, the essential consequences that the managers point out (in the relevance order), through the semistructured interview script to develop a first class service in the customer service where they are take part:

Table 2: Evaluation of professional competencies in the service

\begin{tabular}{|c|c|c|}
\hline Competencies & $\%$ & Managers \\
\hline Team work & 100 & CI, CT, CA \\
\hline Self-development & 100 & CI, CA, CT \\
\hline Self-development & 100 & CI, CA, CT \\
\hline Written communication & 100 & CI, CA, CT \\
\hline Oral communication & 100 & CI, CA, CT \\
\hline Negotiation & 100 & CI, CT, CA \\
\hline Organization & 100 & CI, CT, CA \\
\hline
\end{tabular}




\begin{tabular}{|c|c|c|}
\hline Quality-orientation & 100 & $\mathrm{CI}, \mathrm{CA}, \mathrm{CT}$ \\
\hline Criativity and Innovation & 67 & $\mathrm{CA}, \mathrm{CT}$ \\
\hline Flexibility & 67 & $\mathrm{CI}, \mathrm{CT}$ \\
\hline Conflict management & 67 & $\mathrm{CI}, \mathrm{CT}$ \\
\hline Systemic vision & 67 & $\mathrm{CI}, \mathrm{CT}$ \\
\hline Interpersonal relationship & 67 & $\mathrm{CA}, \mathrm{CT}$ \\
\hline Customer-orientation & 67 & $\mathrm{CA}, \mathrm{CT}$ \\
\hline Ability of working under pressure & 33 & $\mathrm{CI}$ \\
\hline Results orientation & 33 & $\mathrm{CI}$ \\
\hline Planning & 33 & $\mathrm{CI}$ \\
\hline Decision making & 33 & $\mathrm{CI}$ \\
\hline Entrepreneuship & 0 & - \\
\hline Leadership & 0 & - \\
\hline
\end{tabular}

The contributions which this representative chart brings are relevant to the study. Out of the twenty (20) competencies presented to the managers, only two (2) remained out of the indications of all of them: entrepreneurship and leadership, which does not mean that the people who do not present these competencies won't develop themselves or will be allocated to other professional activities.

Six (6) competencies were suggested by only two managers: creativity and innovation, flexibility, conflict management, customer guidance, interpersonal relationship and systemic vision; what can be observed is the balance between the indications: the CT manager suggested all of these, the CI manager indicated three and the Ca manager indicated 3.

Chart (4) competencies were indicated only by a manager: capacity to work under pressure, result-oriented, planning and decisionmaking. These competencies were indicated only by one of the managers and it is interesting to observe that it is the same manager who did these indications. What can be inferred is that in spite of the three service teams having the same focus, the CI manager may have realized that in his sector there is some situation that needs the presence of such competencies.

On the other side, the detailed investigation of the factors which are behind this individualized perception compared to the other indications is necessary, which suggests the continuation of this study in this case in particular due to the opacity of the analysis.

Eight (8) competences were indicated by all the managers: self-development, selfmotivation, oral communication, written communication, negotiation, qualityorientation and tem-work. Following the orientations proposed by [33], "the researcher identifies by the documentary analysis and/or interview, the relevant competencies to the organization.

Afterwards, he both arranges and describes those competencies- which should compose the items of the questionnaires...". Before all those statements, to analyze only the competencies indicated by the three managers was a possibility, which does not finish the study, but rather open possibilities for the continuation of this in the future. The essential competencies in the three areas of customer service in the EI investigated are: self-development, self-motivation, oral communication, written communication, negotiation, quality-orientation, and team work. From this definition, the presentation of the research data of mapping individual competencies performed by the collaborators which are part of the three service teams of the EI follows. This research was conducted through the questionnaire with open questions.

According to [33] "the questionnaire is maybe the most used technique to map relevant competencies to an organizational context". Therefore, it was chosen with the objective of 
mapping the competencies existing in the collaborators. The respondents were fifteen
(15) people, identified through alphabet letters for the preservation of their identities:

Table 3: Profile of the respondents who make up the service teams

\begin{tabular}{|c|c|c|c|}
\hline Respondents & Time in the sector & Education & Gender \\
\hline $\mathrm{A}$ & 10 months & Senior High School incomplete & Female \\
\hline B & 3 years and a half & Undergrate Education, doing Administrtion & Male \\
\hline $\mathrm{C}$ & 2 years & Undergaduate Education, doing Administration & Female \\
\hline $\mathrm{D}$ & 5 months & Undergaduate Education, doing Administration & Female \\
\hline $\mathrm{E}$ & 2 years and a half & Incomplete Undergraduate Education & Female \\
\hline $\mathrm{F}$ & 5 months & Undergraduate Education, doing Administration & Female \\
\hline G & About 1 year & Undergraduate Education, doing Physical Education & Male \\
\hline $\mathrm{H}$ & 1 year & Undergaduate Education, doing Administration & Male \\
\hline I & 4 months & Attending Senior High School & Female \\
\hline $\mathrm{J}$ & 6 months & Attending Senior High School & Male \\
\hline $\mathrm{K}$ & 2 years & Undergaduate Education, doing Administration & Female \\
\hline $\mathrm{L}$ & 6 months & Attending Senior High School & Male \\
\hline M & 6 months & Undergraduat Education, doing Information System & Male \\
\hline $\mathrm{N}$ & Did not inform & Did not inform & Did not inform \\
\hline $\mathrm{O}$ & 1 year and a half & Undergraduate Education, doing Administration & Female \\
\hline
\end{tabular}

Source: Research Data

One can analyze in the respondents' profile represented in the chart above that there are variations which will be able to influence the self-checking of their competencies. There is a mix of time experience in the sector and in the education. As to the gender, there is a balance, eight (8) people of the female gender and six (6) people of the male gender answered and one respondent decided not to identify his time in the sector, education and gender. Below, it follows the data presentation and analysis within the variables identified.

Table 4: Essential competencies in the three service areas offered by the EI

\begin{tabular}{|c|c|c|c|}
\hline Competencies & Respondents who possess & $\%$ & Respondents who do not possess \\
\hline Negociation & A B C D E F G H I J K L M N O & 100 & F \\
\hline Self-development & A B C D E G H I J K L M N O & 93.3 & F O \\
\hline Self-motivation & A B C D E G H I J K L M N & 86.6 & H N \\
\hline Written communication & A B C D E F G I J K L M O & 86.6 & F O \\
\hline Oral communication & A B C D E G H I J K L M N & 86.6 & 86.6 \\
\hline Organization & A B D E F G H I J K L M O & 86.6 & M, C (did not answer) \\
\hline Quality-orientation & A B C D E F G H I J K L N O & 86.6 & G, C (did not answer) \\
\hline Team work & A B D E F H I J K L M N O & \\
\hline
\end{tabular}

Source: Research data

The chart is a representation which presents a widespread view of the results. One can analyze that, with a few exceptions, a great part of the respondents possesses the essential competencies pointed out by the managers in relation to the profile of the sector.
The competency "Negotiation" in the chart above obtained $100 \%$ of identification in the collaborators who work with customer service. This is a positive observation, because it is understood that the alignment in this competency serves the sector. 
The other competencies also presented a high percentage and this observation is positive to the organization, because it is understood that the alignment is significantly close to excellence. However, it is adequate here to stress that the monitoring and the development of competencies (as pointed out by [11], 2004) become necessary for the excellence of the customer service to be complete, reached by all the people who are part of the team (as shown by Performance Research Associates, 2008).

At last, the employer can come across with the need to negotiate something with the internal or external customer and will hardly meet it due to the lack of competence. The respondents A, B, D, E, I, J, K possess all the competencies indicated by the managers of the service teams as essential to the excellence of the service given to the customers in the three services areas of the IE and are capable of acting in any of them; that is positive to the organization due to the alignment warranted with that group of people in all the needs related to customer service. What is possible to analyze is that the indicators of the profile of this group possess variations which deplete the performance hypothesis and the capacity of them to be linked to the gender, education or time working in the sector.

That means that there is not a standard for the high level customer service. It is realized that it is the relevance of the individual perception of their competencies. Even this perception is linked to maturity; the perception maturity and self-knowledge are not concomitant with the variables identified in this group of gender, time of experience in the function and education, as stood out by [47]. To study more, the application of this into other organizational realities is suggested. The respondent $\mathrm{C}$ did not manifest his perception in relation to three of the eight competencies presented to her.

As a hypothesis to this fact, it was understood that the respondent was totally committed with the research which was applied, being able to be investigated in isolation. As a piece of information about the respondent, there is the fact that the respondent has been in the sector some time, that is, she has already experienced the work routines structured along the school year, in addition to studying in the administration area, which enables her to disregard precociously the hypothesis that she has not understood what was placed in the investigation questionnaire for dealing with the use of a language which is not part of her routine.

The respondent $\mathrm{F}$ uses negative answers in three competencies: Self-knowledge and oral Communication, opposing the importance given by [47, 36], respectively about these thematic. The answers given by the same are emphasized only by a NO, or the no accompanied by expressions conjugated in the first person: "I need to be motivated"; "I have difficulty dialoguing".

With those statements, the identification of the respondent for a more complex investigation is carried out to realize which way to follow before a planning of competency development or a collaborative action for the respondent to be helped in other needs come from this investigation.

The respondent $\mathrm{N}$ presents negative perception to the competencies of Written Communication and Organization. It is realized that there are difficulties of mental organization coming from unknown factors. But, the analysis becomes limited due to lack of information, demanded by the company itself: time in the sector, education and gender.

The respondent $\mathrm{O}$ presents negative perception in relation to the competencies: Self-motivation and Oral Communication. According to the respondent, self-motivation occurs only sometimes, for that reason, the answer was classified as not containing this competence. In addition, he cited that selfmotivation depends on self-esteem, then he probably did not interiorize the question, generalize the competency to a state, or called himself unsteady relative to his self-esteem.

However, according to his profile, disregard the ignorance about the proposal placed for the self-analysis of the competency perception, it is understood as possible, because he or she is already in the sector enough time to acquire the necessary knowledge and also for studying in the administration area which routinely approaches subjects related to the proposal of this study.

The respondents $\mathrm{H}, \mathrm{M}$ and $\mathrm{G}$ do not possess only one of the highly essential competencies. It is suggested an analysis used for the 
respondents who do not possess some competency (ies), with emphasis on the development and accompanying of them from a particular investigation. Specifically, the respondent $M$ who does not possess the Quality-oriented competency calls the attention due to the fact that the quality is part of the EI strategy as a pillar in the services offered, then it is a fundamental component pointed out by [19].

In addition, the respondent complements his negative answer saying that he cares only about what is important to him. What is understood is that the work he develops can be first-rate or not, it will depend on the degree of importance that the situation will have for him. Therefore, enhanced attention in the investigation of this case is recommended, observing and analyzing other variables which will be able to help in the decision-making to remain or not with the collaborator, considering, however, that the same one has been six months in the sector and dedicates his undergraduate studies to the information system area, in the technological area.

The analysis performed before each composed situation allowed us realizing and addressing considerations regarding the alignment of strategies and competencies. According to the indicators, it was found that there is a sound alignment between the proposed in the study (as indicated by [33], but not with its depleted maturity, which suggests as described in the text [10], a monitoring and development of the competencies that are not present on people who are part of the customer service team.

The mapping is a highly important instrument for the manager to have conditions to move strategically within his own management, in partnership with his collaborators. The learning consolidation can present itself from this case study and that is worthwhile standing out: it can be performed independent of the marketing branch for any kind of organization. This in particular showed that it is possible to carry out a study of the internal reality of the business.

But, it is important to understand that a investigation inside the company needs to go beyond the simple data obtained. The data are used in the making-decision processes, mainly strategic.
From the moment the company accepts to map and to know its group, its services and its competencies, either aligned or not, it means a step inside the corporate maturation in relation to its integral development. In agreement with what was seen in [9], it is necessary to identify if the processes are aligned or not and acting in the maturity and also having advantage in relation to the competitors.

Even today there are lots of traditional organizations that are centralized in relation to the way they manage their business, ignoring their collaborators in the sense of not knowing them and limiting themselves to superficiality of knowing only the professionals inside the company. In the light of what was seen in [32], the strategic alignment to the competencies serves to make clear the $360^{\circ}$ in the company (employees, administration, customers, suppliers) and each one will be able to understand, commit themselves and walk together to the same direction to the success and the market highlight which in general all companies aim at, this success being represented through postulates placed by the company or verbally announced.

Once identified and mapped the competencies, checked the alignment and verbalized the clarity in the purposes, if there is an alignment between competencies and strategy, it is excellent. Otherwise, it is necessary (as suggested by [10] a planning to be created, developed in order to realize the necessary competencies in the recruitment and selection process. Or still, if the existing professional competences are not aligned to those of the company, it has an equal importance that the competence development plan is designed and monitored with the purpose of enabling the untrained employees or allocating them to functions that are compatible with the existing ones, as indicated by [50].

\section{Conclusion}

The study analyzed the relevance of the alignment between strategy and competencies in the educational area. The case was studied with the fundamental purpose of knowing and describing the organizational competencies (physical structure of service, schedules, technological resources, programs, etc.) and professional (qualified and skilled employees) as a strategy to reach the 
organization objectives with focus on customer service.

In the study, it was possible to find some important aspects belonging to the addressed theme which can be incorporated to the strategies of other educational companies or other sectors, as it was mentioned in the empirical analysis. The study concluded that the alignment is a strategic factor of differentiation in relation to the services. The evidence for that occurred over the presentations of the data and the empiric analysis.

The objectives of the EI - which seeks to offer an outstanding service to the customers - it was realized that they are ascending. The physical structure of service, the available technological resources, the services programs, in relation to the market of the area, in an empiric analysis, has advantages. The team of professionals who evaluate the proposals in practice present themselves interconnected with the company purposes and they feel the satisfaction for being part of an organization that seeks a real alignment, in spite of the continuous challenges coming from controllable factors and mainly noncontrollable. The results found in the survey were valuable and allowed a meaningful analysis about what was proposed, despite leaving gaps that prompt further investigations or even about the same, but with another depth.

It was found that the research has brought to the organization improved visibility, despite the organization having a focus in the alignment; all the involved ones could have their own analysis, being reflected on them and in their environment. In spite of the study having reached its end by structural and methodological issues, it was noted that it contributed to the deepening and improvement of the knowledge related to the theme proposed, as it relied upon the experience of scholars of the area that anchored the theoretical framework giving support to the investigation. In the view of

\section{References}

1.Tureta C, Lima JB (2011) Estratégia como prática social: o estrategizar em uma rede interorganizacional. Revista de Administração Mackenzie, 12(6):76-108.

2.Stewart T, White RE (2007) Strategic purity: a multi-industry evaluation of pure vs. Hybrid the researchers, the results were satisfactory since the proposed objectives were achieved both in the explored theoretical content and in the collection and analysis of the data. However, it is recognized that the subject was not exhausted, and that is positive for revealing possibilities of other studies from this study. The study shows that organizations need to realize the importance of strategic alignment of the human competencies, representing, through their capacity and performance, the company's interests. The alignment occurs in a less traumatic way when the organization invests in strategy communication and relationship with its collaborators.

The selection of personnel from the expected competencies, based on corporate strategy and mapping of the existing competencies is essential to the organization's success and competitive highlight. As it was evidenced, it is not enough that the collaborators are in the situation for a significant time period. As far as the customer service is concerned, it is also necessary: (i) to identify the employees who are aligned with the philosophy, objectives and strategies of the organization; (ii) make sure that each collaborator chosen has the necessary competencies in communication and good relationships with customers; (iii) carry out the necessary trainings periodically, and; (iv) often monitor the results of the work of the collaborators and the customer satisfaction.

It is important to consider that the study of the alignment between strategies and competencies in customer service in the education area becomes relevant to the adequate application of actions related to the profile of Education Institutions, as well as the forms of assistance which support the purchase and consumption of their services. Thus, it is up to the managers of the Education Institutions to plan, implement, guide, monitor, check, discuss and seek alternatives to the institutional demands of customers.

business strategies. Strategic Management Journal, 28(5):553-561.

3. Salanova M, Agut S, Peiró JM(2005) Linking organizational resources and work engagement to employee performance and customer loyalty. Journal of Applied Psychology,90(6):1217-1227 2. 
4.Fleury A, Fleury MTL (2004) Alinhando estratégias e competências. Revista de Administração de Empresas., 44(1):44-57.

5.Minstzberg H, Joseph L, James BQ, Sumantra, G (2006) O processo da estratégia: conceitos, contextos e casos selecionados. Porto Alegre: Bookman.

6.Fleury A, Fleury, MTL (2006) Estratégias empresariais e formação de competências: um quebra cabeça caleidoscópio da indústria brasileira. São Paulo: Atlas.

7.Prahalad CK, Hamel G (1990) The core competence of the corporation. Harvard Business Review, 68(3):79-91.

8. Brandão HP, Bahry CP (2005) Gestão por competências: métodos e técnicas para mapeamento de competências. Revista do Serviço Público, 56(2):179-194.

9.Ferreria DAF, Souza FJM, Souza SMA (2011) Mapeamento de competências gerenciais no tribunal de justiça da Paraíba. In: Encontro de Estudos em Estratégia Porto Alegre: Anpad.

10. Moreira WR, Munk L (2010) O processo de alinhamento entre estratégias e competências organizacionais. Revista Alcance [Eletrônica], 17(2):178-191.

11. Dutra JS (2004) Competências: conceitos instrumentos para gestão de pessoas na empresa moderna. São Paulo: Atlas.

12. Munk L, Carlos ERM. Wellington M, Munk MM (2012) Alinhando estratégia e competências em contexto organizacional: um estudo em uma indústria química. Revista Administração em Diálogo, São Paulo, 14(2):43-75.

13. Castells M, Cardoso G (2015) the Network Society: From Knowledge to Policy. Washington, DC: Johns Hopkins Center for Transatlantic Relations.

14. Batinic B, Appel M (2013) Mass communication, social influence, and consumer behavior: two field experiments. Journal of Applied Social Psychology, 43(7):1353-1368.

15. Treacy M, Wiersema F (2004) the Discipline of Market Leaders. In http://www.buddykluin.nl/html/downloads/disc iplineofmarketleaders.pdf. Acessed in 16/06/2016.

16. De Benedicto SC, De Benedicto GC, Stieg CM, Andrade GHND (2012) Postura metodológica indutiva e dedutiva na produção científica dos estudos em administração e organizações: uma análise de suas limitações e possibilidades. Revista Economia \& Gestão, Minas Gerais, 12(30):4-19.

17. Ingersoll GL, Witzel PA, Smith TC Using organizational mission, vision, and values to guide professional practice model development and measurement of nurse performance. The Journal of nursing administration, 35(2):86-93.

18. Mirvis P, Googins B, Kinnicutt S (2010) Vision, mission, values: guide posts to sustainability. Organizational Dynamics, 39(4):316-324.

19. Le Boterf G (2006) Desenvolvendo a competência dos profissionais. Porto Alegre: Bookman.

20. Liang CJ, Lin YL, Huang HF (2013) Effect of core competence on organizational performance in an airport shopping center. Journal of Air Transport Management, 31, 23 26.

21. Chiniara M, Bentein K (2016) Linking servant leadership to individual performance: Differentiating the mediating role of autonomy, competence and relatedness need satisfaction. The Leadership Quarterly, 27(1):124-141.

22. Belfort RM, Santos EFMS, Tadeucci MSR (2012) Gestão por competências: um novo modelo de gerenciamento. Revista UNI, Imperatriz, 2(2):39-53.

23. Fleury A, Fleury MT (2001) Estratégias empresariais e formação de competências: um quebra-cabeça caleidoscópio da indústria brasileira. São Paulo: Atlas.

24. Dias AT, Gonçalves CA, Colta KAPG (2007) Fatores estratégicos e desempenho de empresas em ambientes turbulentos: o caso das companhias brasileiras abertas no período 1996-2001. Revista de Administração Contemporânea Eletrônica, 1(3):86-106.

25. Picarelli V (2002) Gestão por competências. In: Boog G, Boog M. Manual de gestão de pessoas e equipes: Estratégias e tendências. 1:215237.

26. Zarifian P (2003) Objetivo competência: por uma nova lógica. São Paulo: Atlas.

27. Hitt MA, Ireland R, Hoskisson RE (2011) Administração Estratégica. São Paulo: Cengage Learning.

28. Faria S, Oliveira, VFD, Forner L, D'astuto F (2005) Competências do profissional da informação: uma reflexão a partir da Classificação Brasileira de Ocupações. Ciência da Informação, 34(2):26-33.

29. Leme R (2005) Aplicação prática de gestão de pessoas: mapeamento, treinamento, seleção, avaliação e mensuração de resultados de treinamento. Rio de Janeiro: Quality mark.

30. Mills J, Platts K, Bourne M, Richards's r (2002). Strategy and performance: Competing 
through competences. Cambridge: Cambridge University Press.

31. Slocum J, Lei D, Buller P (2014) Executing business strategies through human resource management practices. Organizational Dynamics, 43(2):73-87.

32. Pires AK, Prata CF, Santos DMD, Brandão HP, Moraes H, Caravalho I MD, Monteiro JC, Dias JC, Filho JVE, Oliveira MMS, Marques MIC, Amaral PA, Araújo PBDC, Hashimoto R, Machado SS, Dantas VC (2005) Gestão por competências em organizações de governo. Brasília: ENAP.

33. Gimenes CH (2009) Formação de competências gerenciais: um fator de desenvolvimento de lideranças - estudo de caso no IPEN.109 Dissertação (Mestrado em Ciências) Universidade de São Paulo, São Paulo.

34. Barbosa ACQ, Bitencourt C (2010) A gestão de competências. In: Bitencourt C (Org.) Gestão Contemporânea de pessoas: novas práticas, conceitos tradicionais. Porto Alegre: Bookman.

35. Javidan M (1998) Core Competence: what does it mean in practice? International Journal of Strategic Management, 31(1):60-71.

36. Macarenco I (2006) Gestão com pessoas gestão, comunicação e pessoas: comunicação como competência de apoio para a gestão alcançar resultados humanos.248 Tese (Doutorado em Comunicação) - Universidade de São Paulo, São Paulo.

37. Kaplan R, Norton D (2006) Como aplicar uma nova estratégia sem causar distúrbios na organização. Harward Business Review, 84(3):68-77.

38. Oliveira AAR, Zago CC (2008) Compatibilidade entre competências individuais e organizacionais: um estudo de caso em uma organização não governamental - ONG. Revista Produto \& Produção, São Paulo, 9(1):41-53.

39. Amaral RM, Garcia LG, Faria LILD, Aliprandini DH (2008) Modelo para o mapeamento de competências em equipes de inteligência competitiva. Ciência da Informação, Brasília, 37(2):7-19.
40. Santos FMT, Greca IM (2013) Metodologias de pesquisa no ensino de ciências na América Latina: como pesquisamos na década de 2000. Revista Ciência \& Educação, São Paulo, 19(1):15-33.

41. Laville C, Dionne JS (2007) A construção do saber. Belo Horizonte: UFMG.

42. Gil AC (2008) Métodos e técnicas de pesquisa social. São Paulo: Atlas.

43. Yin RK (2015) Estudo de caso: planejamento e métodos. Porto Alegre: Bookman.

44. Oliveira TMV (2001) Amostragem não probabilística: adequação de situações para uso e limitações de amostras por conveniência, julgamento e quotas. Revista Administração On Line, 3(2):1-16. In http://www.fecap.br/adm_online/art23/tania2.h tm. Acessed in 20/07/2016.

45. De Benedicto SC (2011) Apropriação da inovação em agrotecnologias: estudos multicasos em universidades brasileiras. 2011. 309 p. Tese (Doutorado em Administração) Universidade Federal de Lavras, Lavras.

46. Brandão HP, Guimarães TA (2001) Gestão de competências e gestão de desempenho: tecnologias distintas ou instrumentos de um mesmo constructo? Revista de Administração de Empresas 41(1):8-15.

47. Robbins SP (2009) Comportamento organizacional. São Paulo: Prentice Hall.

48. Rossi CM, Neves N (2013) Apoio virtual. Revista VOCE/SA, São Paulo, 179.

49. Brandão HP, Guimarães TA (2001) Gestão de competências e gestão de desempenho: tecnologias distintas ou instrumentos de um mesmo constructo? Revista de Administração de Empresas, São Paulo, 41(1):8-15.

50. Brandão HP, Guimarães TA, Borges-Andrade JE (2001) Competências profissionais relevantes à qualidade no atendimento bancário. Revista de Administração Pública, 35(6):61-81. 